Hanna Łaskarzewska

Warszawa

\title{
Kartoteka kopii znaków własnościowych w Pracowni Dokumentacji Księgozbiorów Historycznych Biblioteki Narodowej
}

W 1990 r. w Pracowni Dokumentacji Księgozbiorów Historycznych rozpoczęto tworzenie warsztatu informacyjnego dla potrzeb prac własnych Pracowni, jak i dla osób spoza BN, prowadzących własne badania księgoznawcze. Jako pierwsze powstały dwie kartoteki księgozbiorów historycznych:

- kartoteka kolekcji, które wchodzą w skład zbiorów BN;

- kartoteka księgozbiorów historycznych, ułożona chronologicznie według wieków, a w ich ramach według nazw ich właścicieli oraz w układzie topograficznym, według miejsc ich powstania i kolejnych lokalizacji.

Obie kartoteki powstawały na podstawie autopsji zbiorów bądź wyszukiwania informacji z literatury przedmiotu, a także zbierania materiałów przez współpracowników z wielu bibliotek krajowych i zagranicznych. Często do Pracowni trafiały informacje o zespole ksiąg oznaczonych podobnymi, lecz nierozpoznanymi znakami własnościowymi. Zazwyczaj przysyłano nam ich kopie do identyfikacji.

Niezbędnym zatem dopełnieniem kartotek właścicieli zbiorów, a także powstałego równolegle indeksu nazw właścicieli zbiorów bibliotecznych do Zbiorów polskich Edwarda Chwalewika (wyd. w latach 1926-1927 w układzie topograficznym; indeks właścicieli obejmuje kilka tysięcy zapisów), stała się kartoteka kopii znaków własnościowych. Jej zalążkiem były gromadzone kserokopie znaków z dostępnych publikacji polskich i zagranicznych (polonika proweniencyjne), uzupełniane dzięki współpracy z bibliotekami krajowymi oraz zagranicznymi. Otrzymywane informacje o polskich księgozbiorach historycznych uzupełniane były najczęściej kopiami występujących w nich różnorodnych oznaczeń własnościowych. 
Zespół Pracowni prowadził również własne kwerendy dotyczące znaków własnościowych podczas wyjazdów służbowych (w ten sposób zebrano kopie znaków z bibliotek poznańskich, cieszyńskich, seminaryjnych w Płocku i Włocławku, kapitulnej w Łowiczu itd.). Gromadzony zbiór powiększał się także dzięki pracom w różnych komórkach organizacyjnych Biblioteki Narodowej, między innymi w magazynie zasobu wymiennego. Wyszukując znaki własnościowe, uzupełniano informacje i dane o właścicielach księgozbiorów z różnych okresów historycznych. Większość znaków kopiowaliśmy (w zależności od ich jakości i czytelności). Najzasobniejszy zbiór kopii znaków uzyskaliśmy pracując przy książkach z dużego transportu zbiorów zwróconych z ZSRR w 1985 r., które przekazano do Biblioteki Narodowej. Były to głównie fragmenty polskich księgozbiorów (prywatnych, instytucjonalnych, w przewadze szkolnych) zagrabionych przez ZSRR w latach okupacji i po zakończeniu II wojny światowej z Ziem Wschodnich II RP, a następnie wywiezionych do Moskwy.

Wybieraliśmy również i kopiowaliśmy znaki własnościowe z dubletów i druków zbędnych przekazanych przez Bibliotekę Polską w Paryżu do $\mathrm{BN}, \mathrm{z}$ przeznaczeniem dla bibliotek działających w skupiskach Polaków w krajach b. ZSRR.

Obecnie kartoteka zawiera kopie znaków własnościowych 796 prywatnych właścicieli księgozbiorów i 285 instytucji (łącznie 1081 właścicieli). Trzeba jednak zaznaczyć, że w większości przypadków jednemu właścicielowi odpowiada więcej niż jeden zidentyfikowany znak własnościowy, w związku z tym liczba kopii znaków przewyższa liczbę haseł właścicieli zbiorów.

Ponadto zgromadzono 1143 kopie znaków, które czekają jeszcze na opracowanie i włączenie do kartoteki; są ułożone alfabetycznie według nazw właścicieli.

Opis dołączony do każdego hasła (właściciel lub instytucja) składa się z: nazwy właściciela; dat życia lub działalności instytucji; krótkiej notki o losach księgozbioru; wyszczególnienia ponumerowanych znaków wraz z informacją o ich rodzaju (superekslibris, ekslibris, pieczątka, odręczne zapiski itd.); informacji o źródle, z którego pochodzi dana kopia (bezpośrednio z książki, z publikacji).

Większość znaków własnościowych, zbieranych przez Zespół Pracowni bezpośrednio z książek, pochodzi z druków XIX i XX w. (do końca II wojny światowej).

Kopie znaków zgromadzone w kartotece służyły wielokrotnie jako materiał ilustracyjny do publikacji, do porównań i prawidłowych ustaleń właściciela danej książki lub części kolekcji, do prześledzenia rozproszeń i przemieszczeń polskich księgozbiorów. 